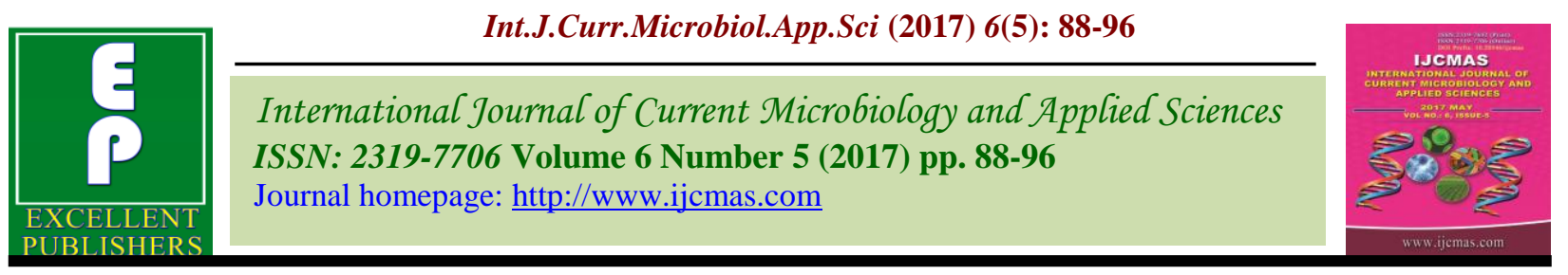

Review Article

https://doi.org/10.20546/ijcmas.2017.605.011

\title{
The Critical Review on Integrated Weed Management in Urd Bean
}

\author{
Shweta, Manu Malik* and Amandeep \\ College of Agriculture: CCSHAU, Hisar, India \\ *Corresponding author
}

\begin{abstract}
A B S T R A C T
\end{abstract}
\section{Keywords}

Urd bean, Integrated weed management, weed control, seed rate.

Article Info

Accepted:

04 April 2017

Available Online:

10 May 2017
The majority of grassy weeds found in urdbean during kharif season include Echinochloa colona, E. crusgalli. In India, production of pulses is around 19.3 million tonnes (ESI 2015) with a very low average productivity of $764 \mathrm{~kg} / \mathrm{ha}$. Currently, total area under pulses is 26.3 million ha. Their cultivation over poor, marginal and nutrient deficient soils, unfavourable weather conditions, unavailability of quality seeds, poor socio-economic conditions of the growers, and severe weed infestation especially during mansoon season, poor postharvest handling and inadequate market support are some major constraints in realizing the potential of available technologies for the pulse production

\section{Introduction}

Urd bean or black gram (Vigna mungo L.) is one of the important pulse crops of kharif season. It has wide adaptability and can be grown round the year in different agroecological regions of the country. It is a rich source of protein $(24 \%)$ fat $(1.5 \%)$ and minerals and plays an indispensable role in human diet and fertility build up of soil. The productivity of urdbean is quite low (473 $\mathrm{kg} / \mathrm{ha}$ ) owing to several constraints. One of the formidable reasons of low productivity of urdbean in kharif season is severe weed infestation. Weeds, which emerge simultaneously with the crop grown very fast because of hot and humid weather and offer still competition with crop plant for natural resources at all the stages of growth. The yield reduction in urdbean due to weeds may be as high as $70 \%$ (Dubey et al., 1984). Therfore, it becomes imperative to control weeds at appropriate time.

The majority of grassy weeds found in urdbean during kharif season include Echinochloa colona, E. crusgalli, Eleusine indica, Cyperus rotundus, C.iria, Cynodon dactylon, and Sorghum halepense.The commen broad leaved weeds are Trianthema Monogyna, Celosia urgentea, Amaranthus spp, Virdis spp, Cleome viscose, Commelina benghalensis, Cucumis trigonus and physalis minima. The degree of competition offered by these weeds in urdbean is quite intense at early vegetative stages (25-30 days after 
sowing) which is considered as critical period of crop-weed competition (Kasasian and Sceyave, 1969). Weeds remove plant nutrients more efficiently than crop plants.

There are several control measures of weeds i.e. chemical, mechanical and biological control. The chemical control of weeds is more efficient less expensive and time saving, but it cannot completely eliminate the need of manual (mechanical) and cultural practices.

Since application of single herbicide may not be affective in providing broad spectrum weed control, hence, application of pre and post emergence herbicides either in combination or sequence, or integration with manual weeding may be more beneficial. Pertinent review on integrated weed management and its effect on yield and yield attributes of urdbean have been presented here.

\section{Common weed flora in urdbean}

Echinoclona crusgali, Digitaria spp, Cyperus iria and C.rotundus, among the monocot and Justica quinquea qualaris, Merremia spp, Digera muricata, Phyllanthus spp and Euphorbia spp. Among the dicot weeds have been reported as common weeds of urdbean (Mehta and Boonlia, 1982) at Kota, Rajasthan. Bisen et al., (1982) reported that the predominant weed species in urdbean at Jabalpur, were Cyperus spp. (43.3\%) followed by Echinochloa spp (15.3\%) and Cynodon dactylon (11.2\%). Singh and Singh (1988) reported the Echinochloa spp., Ageratum conyzoides, celosia argentea, Euphorbia hirta, Panicum spp, Achyranthus aspera and Xanthium strumarium as the common weeds of urdbean at Ambikapur (M.P.).

The dominant weed flora present in urdbean under Pantnagar conditions were Echinochloa colona, Cyperus royundus, Eleucine indica,
Commelina benghalensis and Brachiaria ramose (Singh et al., 1991). Mishra and Singh (1993) found Echinochloa spp., Cyperus rotundus, Cleome viscose, Celosia argentia, Cucumis trigonus, Elusine indica and Physalis minima were the most problematic weeds in urdbean at Pantnagar.

In the conditions of Kanpur, Tranthema monogyna, Echinochloa colona, Cyperus rotundus, Phyllanthus niruri, Dactyloctenium aegyptium, Commelina bengalensis and Eclipta alba as the most problematic weeds of urdbean (Tewari et al., 1993). Sharma and Nayital (1993) at Bajaura (Kullu) reported that Dactyloctenium aegyptium, Digitaria sanguinalis, Eleusine indica, Cyperus rotundus, Cynodon dactylon, Commelina benghalensis, Amaranthus viridis and Polygonum spp were among the common weeds of urdbean, the weeds mostly prevalent in urdbean Trianthema portulacastrum, Cynodon dactylon and Cyprus rotundus under the conditions of Coimbatore (Ramanathan and Chandra Shekharan, 1998).

Kumar et al., (2000) at IARI, New Delhi reported the major weed $s p p$ in urdbean were Dactyloctenium aegyptium, Digitaria sanguinalis, Echinochloa colona, Digera arvensis, commelina benghalensis, Trianthum portulacastrum and Amarantus viridis. Whereas Reddy et al., (2000) reported in the conditions of Rajendranagar, Hyderabad, Cyperus rotundus, Panicum spp, Echinochloa colona, Amaranthus viridis, Parthenium hysterophorus, Trianthema portulacastrum, cleome viscose, Portulaca oleracea and digera arvensis as important weeds of urdbean crop.

Rao et al., (2001) predominant weed flora of the green gram was comprised of Acalypha spp., Euphorbia spp., Phyllanthus niruri, Commelina benghalensis cynodon dactylon and tea weed (Polypodium lachnopus). 


\section{Losses caused by weeds}

Weeds are notorious pests and reduce yield of crop plants by competing for nutrients, moisture, light and space (Tadulingam and Venkatanarayana, 1995b and Isely, 1962). Weeds offer severe competition for essential nutrients like nitrogen, phosphorus and potash (Vengris et al., 1995; Pandey and Rao, 1965). Undoubtedly weeds reduce the yield of urdbean. The degree of reduction varies from place to place depending upon prevailing climate conditions.

Vats and Sawhney,1981 indicated that the loss in grain yield under unweeded check was to the tune of 50 per cent whereas it was 41 , 31 , and 39 per cent when weeds were removed at 2, 4 and 6 weeks of sowing, respectively. Singh and Singh (1981) reported that under uncontrolled weed situation throughout entire crop season, yield of urdbean and mungbean was reduced by 72 and more than 80 per cent, respectively. The work done at Pantnagar revealed that there was 87 per cent yield reduction in urdbean when weeds competed for full season (Singh et al., 1982). They further observed that yield was reduced by 28.2 and 37.7 per cent when weeds competed with urdbean crop for first 30 and 45 days, respectively. Dubey et al., (1984) reported a yield loss of 70 per cent in blackgram due to weed infestation.

Parto and Prusty (1994) from Bhubaneshwar reported 67.7 per cent reduction in grain yield of mungbean due to weeds. Singh et al., (1996) observed that weed competition with the crop for full crop season resulted in 49 per cent reduction in grain yield of summer mungbean under the conditions of Jabalpur. Reddy et al., 1998 reported that weeds caused 40-50 per cent loss in seed yield in greengram during kharif. Kumar et al., (2000) reported that weeds reduced the yield of kharif pulses to the extent of $80-90$ per cent due to their competition with crop plants for nutrients, moisture, light and space.

\section{Critical period of weed competition}

Critical period of weed competition is the shortest time span during the crop growth when weeding results in the maximum economic returns. A lot of variations in critical period of weed crop competition have been observed from crop to crop at different locations.

Bhan et al., (1970) at pantnagar, recorded 50 per cent reduction in grain of mungbean with one hand weeding had done at 30 DAS as compared to weed free situation upto 60 DAS. Rethinam et al., (1976) reported the initial period as most sensitive to mungbean. Vats and Vasu (1977) concluded that hand weeding done at 30 and 50 DAS were quite effective in controlling weeds. They further indicated that the critical period of crop weed competition in mungbean was from four to six weeks after sowing. Vats and Sawhney (1981) found 4-6 weeks of sowing as critical period of weed competition in urdbean at Ludhiana. Bhan et al., (1982) concluded that hand weeding done at four weeks after sowing increased the yield of cowpea at Hisar. Singh and Singh (1982) from Pantnagar indicated that initial 20-30 DAS in urdbean was most critical for crop weed competition. They further noticed that the maximum yield was obtained from urdbean when kept free from weeds for first 30 days.

Competition for the first 30 days resulted into an average yield reduction of 29.2 per cent, whereas, competition for the 60 days resulted into 71.1 per cent reduction in grain yield (Anonymous, 1984). Munhbean yield was the highest when crop was kept free from weeds during initial 30 days under Junagarh, Gujrat conditions (Raghvansi et al., 1985). The highest grain yield and the lowest weed dry 
weight in mungbean field were observed when weeds were removed in between 35 and 45 DAS (Kolar and Dhingra, 1986).

Patro and Prusty (1994) computed the maximum benefit cost ratio (0.95) when weeding was done at 20 and 30 DAS. Singh et al., (1996) from Jabalpur indicated that critical period of crop-weed competition in summer mungbean was in between 15 and 45 DAS. Kumar et al., (2000) reported weed removal 25 DAS, reduced the weed population significantly over weedy check.

\section{Effect of inter culture practices on weeds and urdbean}

Inter culture practices such as hand weeding by khurpi and hoeing by country plough in between the rows, are chiefly aimed at destroying the weeds.

Panwar and Singh (1977) indicated that yield of mungbean can be doubled by doing hand weeding at 20 DAS and quite effective in controlling the weeds as compared to unweeded plot. The work done at Jabalpur revealed that one hand weeding at 21 DAS in urdbean was the most advantageous and economic (Bisen et al., 1981).

Singh and Singh,1985, reported that two hand wgeeding 20 and 35 DAS led to an enhance of 54.6 per cent increase in grain yield of mungbean over unweeded control and was significantly superior to pendimethalin @ $0.75 \mathrm{~kg} / \mathrm{ha}$ and closer row spacing $(20 \mathrm{~cm})$. Soni et al., (1988), observed that at Jammu single hand weeding done at 20 DAS in urdbean was more effective than one interrow cultivation. Singh and Singh (1988) at Ambikapur (H.P) found two hand weeding at 20 and 40 DAS significantly superior over to $1.0 \mathrm{~kg}$ ai/ha alachlor application in term of yield. While according to Borah (1994) 93 percent and 85 per cent yield of mungbean can increase by one hand weeding at 20 or 30 DAS, over weedy check.

Balyan and Gogoi (1998) under the conditions of Assam reported that one hand hoeing at 20 DAS results the highest grain yield of urdbean and was an economically viable practice with higher weed control efficiency. Kumar et al., 2000 reported that one hand weeding 25 DAS was significantly superior to weedy check. Rao et al., (2001) reported that hand weeding, 3 weeks after sowing followed by hoeing, 5 weeks after sowing, recorded higher grain yield than that of pendimethalin spray + hoeing at 3 and 5 weeks after sowing.

\section{Chemical control}

Alachlor, metalachlor and pendimethalin are the common herbicides used in pulses. Rao (2000) reported that alachlor shows the effect up to 6-8 weeks and does not last long enough in soil as its half life is 21 days, while metalachlor provides effective weed control for 10-14 weeks having half life as 3-5 months.

At Kanpur by Panwar and Singh (1980), revealed that pre-emergence spray of nitrofen @ $1.0 \mathrm{~kg}$ ai/ha alone or in mixture with alachlor@1.0 kg ai/ha controlled the weeds effectively besides, giving the higher yield of mungbean and maximum net income.

\section{Integrated approach for weed control}

Continuous use of herbicides may cause environmental pollution and plants may lead to development of resistance against these chemicals. Therefore, it is necessary to utilize more than one methods of weed control for sustaining the productivity and profitability of crops and cropping system. From different experiment conducted all over country, it can be interpreted that combined use of chemical 
and one hand weeding yielded better than any single component.

At Gwalior, Jain et al., (1997) compared the efficacy of different methods of weed control in black gram and found that hand weeding at 20 and 30 DAS along with the pre plant application of fluchloralin @ $1.0 \mathrm{~kg} / \mathrm{ha}$ was the most effective in controlling major weed flora and produced the highest yield. Use of pendimethalin@1.5 kg ai/ha and one hand weeding at 30 DAS in urdbean field was found to be highly effective in controlling the weeds under the conditions of Coimbatore (Ramanthan and Chandra Shekharan, 1998).

Reddy et al., (2000) from Hyderabad, reported that application of any one of the herbicides like pendimethalin, metolachlor and alachlor each @ 1.5 kg/ha to blackgram was very much effective in controlling weeds and gave at par yield to that of hand weeded crop.

Malik et al., (2000) from Hisar reported that performance of trifluralin $0.75 \mathrm{~kg} / \mathrm{ha}$, linuron $0.75 \mathrm{~kg} / \mathrm{ha}$ and acetachlor $1.0 \mathrm{~kg} / \mathrm{ha}$ (all pre emergence) each integrated with one hand weeding at 30 DAS was superior to their alone application against weeds in mungbean. Results of the experiments conducted by Ramamoorthy and Lakshmanachary (2001) in Pondicherry revealed that urdbean produced the highest biomass with pre-emergence application of alachlor @ $1.0 \mathrm{~kg} / \mathrm{ha}+$ one hand weeding at 20 DAS.

\section{Effect of seed rate on growth, yield and} yield attributes

The optimum level of seed rate to be used seems to differ depending upon the environmental conditions, crop species and growth habit. In congenial environment that permits an adequate period for vegetative and reproductive growth, most of the pulses varieties show a little change in yield with large variation in seed rate as has become evident from studies carried out in North India (Panwar, 1978).

In 1992, Gupta observed significantly higher total dry matter accumulation per plant in mungbean at lowest seed rate of $20 \mathrm{~kg} / \mathrm{ha}$ as compared to 25 and $30 \mathrm{~kg} / \mathrm{ha}$. He also reported significant effect of seed rates on initial and final plant population and mortality of mungbean whereas plant stand/ha increased with increase in seed rate from 20$30 \mathrm{~kg} / \mathrm{ha}$. Plant height increased with increase in seed rate from 20 to $30 \mathrm{~kg} / \mathrm{ha}$, while number of trifoliate leaves was higher at lower seed rate of $20 \mathrm{~kg} / \mathrm{ha}$ as compared to 25 and $30 \mathrm{~kg} / \mathrm{ha}$ at all the growth stages in mungbean (Gupta, 1992). At Ludhiana and Sriganganagar in mungbean during spring season a seed rate of $35 \mathrm{~kg} / \mathrm{ha}$ produced taller plant in comparison to lower seed rate (AICPIP, 1993).

Singh (1993) reported that seed rate of 20 and $25 \mathrm{~kg} / \mathrm{ha}$ produced significantly smaller plants in mungbean + urdbean crop than that of 30 $\mathrm{kg} / \mathrm{ha}$ seed rate at maturity, while from Morena, M.P. Tomer et al., (1996) reported that the dry matter accumulation at all growth stages was higher at a seed rate of $20 \mathrm{~kg} / \mathrm{ha}$ in comparison to 30 or $40 \mathrm{~kg} / \mathrm{ha}$.

Pok Padi and Ptradilok (1993) from a field study at Kesetsart University (Thailand) reported that yields of mungbean and urdbean generally increased with increasing plant density while pods per plant were affected adversely. Singh and Sahu (1998) observed no significant response to increasing seed rate from 30 to $35 \mathrm{~kg} / \mathrm{ha}$ in spring planted mungbean at Pantnagar. Kumar et al., (2000), at Hisar Haryana observed that by increasing plant population increased the grain yield of summer planted mungbean. Rao et al., (2001) conducted the experiment at Bidar Karnataka 
and observed that grain yield of green gram differed significantly due to row spacing. The closer row spacing of $30 \mathrm{~cm}$ recorded significantly higher grain yield $(1214 \mathrm{~kg} / \mathrm{ha})$ than 45 and $60 \mathrm{~cm}$.

\section{Effect of weed management on nutrient uptake}

Yadav et al., (1985) studied the crop weed competition in mungbean planted during rainy season and observed that weeds removed $132.2 \mathrm{~kg}$ nitrogen, $17.6 \mathrm{~kg}$ phosphorus and $130.1 \mathrm{~kg}$ potassium per hectare in unweeded control, whereas, the crop utilize only $12.4 \mathrm{~kg}$ nitrogen, $5.3 \mathrm{~kg}$ phosphorus and $10.3 \mathrm{~kg}$ potassium per hectare.

Kundra et al., (1991) found that effective weed management through fluchloralin @ $0.75 \mathrm{~kg} / \mathrm{ha}$ resulted in an uptake of 111.4, 22.7 and $97.5 \mathrm{~kg} \mathrm{~N}, \mathrm{P}$ and $\mathrm{K}$ per hectare, respectively by the crop and allowed only 3.1, 0.7 and $4.1 \mathrm{~kg}$ per hectare NPK to be depleted by weeds. They also observed that preemergence application of pendimethalin @ $0.75 \mathrm{~kg} / \mathrm{ha}$ and two hand weeding (3 and 5 weeks after sowing) also proved equally effective in increasing uptake of nutrients by the crop. Shweta et al., (2005), reported that weed management through application of alachlor @ 1.5 kg/ha with HW 40 DAS minimum nutrient depletion by the weeds $(0.9,0.2$ and $0.8 \mathrm{~kg} / \mathrm{ha} \mathrm{NPK}$, respectively) and increased the NPK uptake by the crop to the tune of $47.6,66.7$ and 41.8 per cent, respectively over weedy check.

\section{Effect of seed rate on nutrient uptake}

Kanungo (1980) analysed mungbean seeds obtained from a field study and reported that total nitrogen, phosphorus and potassium removal was $165.64,22.70$ and $112.33 \mathrm{~kg} / \mathrm{ha}$ at $20 \mathrm{~cm}$ and $130.71,19.34$ and $81.09 \mathrm{~kg}$ per hectare at $30 \mathrm{~cm}$ row spacing, respectively.
Rai et al., (1982) reported that phosphorus uptake increased with increased in plant density from 0.25 to 0.5 million plants per hectare. Protein content increased as the plant density was decreased by increasing row spacing from 15 to $30 \mathrm{~cm}$, higher protein content in Mungbean at wider row spacing was also recorded by Jain et al., (1988) and Shukla (1991). Singh et al., (1992) observed that the higher content of phosphorus and potassium at $30 \mathrm{~cm}$ row spacing.

Singh (1993) from a study carried out during spring season at Pantnagar on urdbean and mungbean reported that protein content of seeds in both the crops did not differ markedly with varying seed rates from 30 to $40 \mathrm{~kg}$ per hectare in urdbean and 20 to $30 \mathrm{~kg}$ per hectare in mungbean. Also observed that nitrogen, phosphorus and potassium uptake increased with increasing level of seed rate from 20 to $30 \mathrm{~kg}$ per hectare.

Singh and Singh (2000) conducted a field experiment on kharif mungbean at Pantnagar and observed that total uptake of nitrogen was higher with 2.2 lakh plants per hectare as compared to 3.3 lakh plants per hectare.

\section{References}

AICPIP. 1993. Consolidated report on spring/summer pulses Agronomy. Directorate of Pulse Research, Kanpur, pp 5-25.

Anonymous. 1984. Revised index number of whole sale prices in india, Ministry of industry and Company Affairs, Govt. of India, pp7-8.

Balyan, H.C. and Gogoi, S. 1998. Influence of weed control measures and phosphorus levels on weed growth, yield and yield attributes of kharif blackgram. Annual Agriculture Bio Res., 3(2): 167-171.

Bhan, V.M., Balyan, R.S. and Singh, S.P. 1982. Influence of time of weed removal and weed species on the grain yield of 
cowpea. Indian J. Agron., 27(3): 267-271.

Bhan, V.M., Singh, M. and Maurya, R.A. 1970. Weed control in field crops at pantnagar, India Research Repl. 1969-70. Pest Articles and News Summaries, 16(4): 690-701.

Bisen, C.R., Tomar, S.S. and Bajpai, R.P. 1982. Chemical weed control in urdbean (Vigna mungo). Annual Conferences Indian Society of Weed Science (c.f. Weed Abstract, 33(9): 28-86).

Bisen, C.R., Tomar, S.S. and Bajpai, R.P. 1982. Chemical weed control in black gram (Vigna mungo). J.N.K.V.V. Res. J., 16(3): 239-242.

Borah, V.K. 1994. Effect of weed control and fertilizer application of productivity of mung bean under rainfed condition. Annuals of Agri. Res., 15(4): 494-501.

Shweta, Singh, V.K. and Singh, R 2005. Effect of weed Management practices and seed rates on nutrients uptake by urdbean and associated weeds in kharif season. National biennial Conferences, ISWS, PAU, April 6-9. Pp156-157.

Dubey, S.K., Jain, H.C., Kosta, L.D. and Raghu, J.S. 1984. Integrated weed management in soybean. Indian J. Weed Sci., 16(4): 238-243.

Jain, V.K., Chauhan, Y.S. and Chitnis, V. 1997. Effect of cultural and chemical methods of weed management on weeds and yield of blackgram (Phaseolus mungo). Indian J. Agron., 42(4): 661-664.

Isely, D. 1962. Weed identification and control. Iowa State University Press; Am. Iowa, USA, pp 211-215.

Kumar, P., Saraf, C.S., Singh, R. and Chander, S. 2000. Effect of weed management and sulphur fertilization of weeds and yield in green gram and black gram intercropping system. Indian J. Weed Sci., 32(1\&2): 2530.

Kanungo, S.P. 1980. Studies on growth, yield and nutrient uptake in mungbean varieties under various date of planting and row spacing during summer season. Thesis, MSc. G.B.P.U.A\&T., Pantnagar, 104 p

Kasasian, L. and Sceyave, J. 1969. Critical period of weed competition. PANS, 15(2): 208-212.

Kundra, H.C., Gosal, K.S. and Brar, H.S. 1991. Effect of weed management practices on nutrient uptake by summer mungbean (Vigna radiate (L.)wilczek) and associated weeds. Indian J. Weed Sci., 23(3\&4): 31-35.

Malik, R.S., Yadav, A. and Malik, R.K. 2000. Efficacy of trifluralin, linuron and acetachlor against weeds in mungbean (Vigna radiata). Indian J. Weed Sci., 32(3\&4): 181-185.

Mehta, I. and Boonlia, D.S. 1982. Comparative efficacy of different herbicides for control of weeds in urd. Pesticides, 16(15): 1516.

Mishra, O.P. and Singh, G. 1993. Weed management in urdbean (Vigna mungo). In: Integrated weed management for sustainable agriculture. Proceeding of an Indian Society of weed Science, International Symposium, Hisar, Nov.1820, III, 154-155.

Pandey, H.K. and Anant Rao, N.K. 1965. Absorption of nutrients by crop plants and associated weeds and its relationship with crop yield. Indian J. Agron., 10(3): 306312.

Panwar, K.S. and Singh, J.P. 1977. Efficacy of mechanical and chemical weed control methods in greengram. Abstract, Weed Science Conference Workshop, India, Paper No. 79, 47 c.f. Weed Abstract, 27(2): 4068.

Panwar, K.S. 1978. All India Subject Matter Specialist Seminar $\mathrm{n}$ Pulses production technology, 28-30 August, 1978. CSAUAT, Kanpur/Ministry of Agri. Development of Agriculture, U.P.

Panwar, K.S. and Singh, J.P. 1980. Weed control studies in green gram. Indian $J$. Agron., 25(1): 132-135.

Patro, H. and Prusty, J.C. 1994. Integrated weed management in mungbean (Vigna radiate L.). Indian J. Weed Sci., 26(2): 79-80.

Pokpadi, A. and Ptradilok, H. 1993. Response of genotype of mungbean and blackgram to planting dates and plant population 
densities. Kaselsart Natural Sci., 274: 395-400.

Rao, S., Veerana, V.S. and Rao, S. 2001. Response of greengram to row spacing and weed management practices. Karnataka J. Agri. Sci., 14(3): 777-778.

Rao, V.S. 2000. Principle of weed science. Second edition, oxford and IBH. Publishing Company private limited, New Delhi, pp 71-73.

Ramanathan, S.P. and Chandrashekharan, B. 1998. Weed management in blackgram. Indian J. Agron., 43(2): 318-320.

Reddy, M.D., Reddy, C.N. and Devi, M.P. 1998. Effect of herbicides application on weed control and seed yield of greengram in alfisols during rainy season. Indian $J$. Weed Sci., 30(3-4): 206-208.

Rethinam, P., Sankaran, M., Sankaran, S. and Morchan, Y.B. 1976. Studies on crop weed competition in greengram under irrigated condition. Madras Agric. J., 63(8-10): 464-466.

Gupta, Vikas, Singh, Mahender, Kumar, Anil, Sharma, B.C., and Kher, Deepak. 2013. Influenced of weed management practices on weed dynamics and yield of urdbean (Vigna mungo) under rainfed conditions of Jammu. Indian J. Agron., 58(2): 220225.

Jain, V.K., Chauhan, Y.S. and Khandekar, M.P. 1988. Effect of genotypes and row spacing on yield and quality of mungbean. Indian J. Pulses Res., 1: 134139.

Pokpadi, A. and Ptradilok, H. 1993. Response of genotype of mungbean and blackgram to planting dates and plant population densities. Kaselsart Natural Sci., 274: 395-400.

Raghuvans, B.R., Goyal, S.N., Patel, J.C. and Malavia, D.D. 1985. Weed completion in mungbean. Indian J. Weed Sci., 17(1): 1821.

Ramamoorthy, D. and lakshmanachary, A.S. 2001. Ecological studies of herbicides on the total biomass of the blackgram crop (Vigna mungo (L.)Hepper Var.T 9 ). Adv. Plant Sci., 14(1): 115-122.
Reddy, M.D., Reddy, C.N. and Devi, M.P. 2000. Effect of herbicides on weed growth and crop performances in riceblackgram cropping system. Indian $J$. Weed Sci., 32(3\&4): 169-172.

Singh, D.K. and Singh, V.K. 2000. Growth and nitrogen uptake pattern of promising urdbean genotype under different sowing dates and plant densities during rainy season. Ann. Agri. Res., 21(3): 456-458.

Singh, A.N., Singh, S. and Bhan, V.M. 1996. Crop weed competition in summer green gram (Phaseolus radiata). Indian J. Agron., 41(4): 616-619.

Singh, A.K. 1993. Performance of mungbean and urdbean varities under varing seed rate during spring/ summer. Thesis, M.Sc., G.B.P.U.A.\&T., Pantnagar, 146p.

Shukla, S.K. 1991. Effect of rhizobium inoculation, plant density and phosphorous level on summer green gram (Vigna radiate L.). Thesis, $\mathrm{PhD}$., N.D.U.A.\&T., Kumarganj, Faizabad.

Sharma, J. and Nayital, S.C. 1993. Weed management in maize+ blackgram intercropping in mid hills sub humid zone of Himachal Pradesh. Indian J. Weed Sci., 25(1\&2): 43-46.

Singh, Digvijay and Shau, J.P. 1998. Performance of mungbean genotypes under different seed rates during spring. Indian J. Pulse Res., 11(2): 144-145.

Singh, G. and Singh, D. 1982. Crop weed competition in urdbean (Vigna mungo L.). In: Annual Conferences of Indian Socity of weed Science, BHU, India PP 39-41.

Singh, G. and Singh, B. 1981. Control of weeds in urdbean and mungbean. Indian Farmer's Digest, 14(5): 21-28.

Singh, G., Singh, B. and Singh, D. 1982. Abstract Annual Conference. Indian Socity of Weed Sci., c.f. Weed Abstract 33(8): 25-66.

Singh, M.C. and Singh, R.P. 1985. Physiological effects on herbicides on seed yield of mungbean. Indian J. Weed Sci., 17 (3): 61-64

Singh, R., Chandel, A.S. and Singh, R. 1991. Weed management in urdbean (Vigna 
mungo L.). Indian J. Weed Sci., 23 (3\&4): 98-100.

Singh, S., Yadav, D.S. and Singh, M 1992. Effect of row spacing and seed rate on nutrient uptake and grain protein of summer blackgram. Narendra Deva J. Agri. Res., 7: 127-130

Singh, V.K. and Singh, R.P. 1998. Chemical weed control in blackgram. Indian $J$. Weed Sci., 20(4): 81-82

Soni, K.C., Singh, H. and Singh, H. 1988. Weed management in urdbean. Indian J. Weed Sci., 20(3): 33-36

Tewari, A.N., Singh, V., Singh, B. and Jain, R.K. 1993. Weed control through herbicides in blackgram intercropped with Seasamum under rainfed conditions. Integrated weed management for sustainable Agriculture. Proceedings of an Indian Socity of weed Science. International Symposium, Hisar, India, Nov. 18-20 Vol. III, pp173-175.

Tomar, S.S., Shrivastava, U.K., Sharma, R.K., Bhadoria, S.S. and Tomar, A.S. 1996.
Effect of seed rate, moisture regimes and phosphorus doses on growth and yield of summer mungbean (Vigna radiata (L)Wilczek). Legume Res., 18(2): 132141.

Vats, O.P. and Sawhney, T.S. 1981. Crop weed competition studies in blackgram. Paper presented at annual conferences of Indian Socity of weed Science, PAU, Ludhiana, Punjab.

Vats, O.P. and Sidhu, M.S.1977. Critical period of crop weed competition in mungbean. In Program and Abstract of Papers, Weed Science Conferences and Workshop in India, Paper No. 77, 45 c.f. weed Abstract, 27(12): 4168-4170.

Vengris, A., Colby, W.W and Drake, M. 1955. Plant nutrient competition between weeds and corns. Agron. J., 47(2): 213-216.

Yadav, S.K., Bhan, V.M. and Kumar, A. 1985. Nutirent uptake by mungbean and associated weeds in relation to herbicides. Indian J. Weed Sci., 17(1): 1-5.

\section{How to cite this article:}

Shweta, Manu Malik and Amandeep. 2017. The Critical Review on Integrated Weed Management in Urd Bean. Int.J.Curr.Microbiol.App.Sci. 6(5): 88-96. doi: http://dx.doi.org/10.20546/ijcmas.2017.605.011 